\title{
PKM Kelompok Ibu Dalam Penanggulangan Narkoba Pada Anak Dan Remaja Di Bukit Doa Meras
}

\author{
Pience Veralyn Maabuat $^{{ }^{*}}$, Agustina Monalisa Tangapo ${ }^{2}$ \\ 1,2Jurusan Biologi, Fakultas Matematika dan Ilmu Pengetahuan Alam, \\ Universitas Sam Ratulangi Manado \\ *Penulis Korespondensi. Email: thealyn@yahoo.com
}

\begin{abstract}
ABSTRAK
Saat ini pengetahuan tentang narkoba dan obat-obatan terlarang perlu disosialisasikan dimanapun, dimulai dari dalam keluarga sampai ke sekolah dan perguruan tinggi bahkan instansi pemerintah serta kantor-kantor swasta. Pengenalan akan bahaya dan pencegahan bukan saja diperlukan di kalangan mahasiswa atau orang dewasa saja, akan tetapi dibutuhkan juga dikalangan siswa sekolah yang mulai tumbuh mencari jati diri juga berlaku bagi anak-anak usia dini. Pendampingan orang tua sangatlah penting, terutama ayah dan ibu dalam keluarga. Hal penting yang perlu diperhatikan saat ini yaitu meningkatnya peredaran narkotika dan jumlah pengguna yang bukan saja dari kalangan orang dewasa tetapi juga siswa sekolah dasar yang mmenjadi korban akibat para sindikat pengedar narkoba yang memasarkan produk dalam bentuk permen, sehingga orang tua juga bisa terkecoh. Untuk itu penting dilakukan suatu kegiatan berupa penyuluhan bagi kelompok Wanita Bukit Doa di Kelurahan Meras Kecamatan Bunaken Kota Manado. Mitra yang dipilih merupakan dua kelompok wanita yang terdiri dari ibu rumah tangga dan wanita bekerja yang berdomisili di Bukit Doa dan sekitarnya dalam wilayah yang sama di Kelurahan Meras Lingkungan III. Metode kegiatan yang dilaksanakan yaitu penyuluhan/sosialisasi dan memotivasi mitra sehingga diharapkan kegiatan ini memberikan pengaruh yang positif sehingga kedepannya bisa lebih waspada dalam menanggulangi Narkoba dan obat terlarang lainnya. Hasil yang diperoleh, kegiatan yang dilakukan melalui media zoom berlangsung dengan baik dan respon yang diterima sangat baik dari peserta yang terdiri dari kalangan ibu-ibu, bapak bapak, remaja dan pemuda. Transfer pengetahuan dari pembicara bisa dilaksanakan dengan terlihatnya respon peserta yang awalnya masih kurang pengetahuannya akan narkoba menjadi tahu dan mengerti. Kegiatan tersebut juga dimanfaatkan oleh para peserta untuk tanya jawab melalui zoom chat.
\end{abstract}

Kata Kunci : Narkoba, Ibu-ibu, Remaja, Pemuda, Anak-anak

\begin{abstract}
Currently, knowledge about drugs and illegal drugs needs to be disseminated anywhere, starting from within the family to schools and colleges and even government agencies and private offices. The recognition of dangers and prevention is not only needed among students or adults, but it is also needed among school students who are starting to grow up looking for identity as well as for young children. Parental assistance is very important, especially fathers and mothers in the family. Important things that need to be considered at this time are the increasing circulation of narcotics and the number of users who are not only adults but also elementary school students who have become victims as a result of drug trafficking syndicates who market products in the form of candy, so that parents can also be fooled. For this reason, it is important to carry out an activity in the form of counseling for the Bukit Doa Women group in Meras Village, Bunaken District, Manado City. The selected partners are two groups of women consisting of housewives and working women who live in Bukit Doa and its surroundings in the same area in Kelurahan Meras Lingkungan III. The method of activities carried out is counseling /
\end{abstract}


socialization and motivating PARTNERS so that it is hoped that this activity will have a positive effect so that in the future they can be more vigilant in overcoming drugs and other illegal drugs. The results obtained, the activities carried out through the zoom media went well and the response received was very good from the participants consisting of mothers, fathers, adolescents and youth. The transfer of knowledge from the speakers can be carried out by seeing the response of the participants who initially lacked knowledge of drugs to know and understand. This activity was also used by the participants for questions and answers via zoom chat.

Keywords: Drugs, mothers, adolescents, youth, children8

\section{PENDAHULUAN}

\section{Analisis Situasi}

Seiring dengan kemajuan zaman memasuki era moderenisasi 4.0 yang membawa perubahan besar dalam kehidupan masyarakat, mulai dari anak-anak sampai dengan orang dewasa. Segala sesuatu begitu dimudahkan untuk diperoleh dan diketahui lewat media social dan internet. Pengetahuan yang bernilai positif dan ilmiah memudahkan untuk setiap anak bangsa Indonesia memiliki pengetahuan yang selalu up to date, akan tetapi kemajuan yang ada dapat disalahgunakan untuk mempermudah melakukan kegiatan yang negatif seperti peredaran narkoba.

Menurut Kepala Badan Narkotika Nasional (BNN) Kota Manado Eliasar Sopacoli yang dikutip dari media online (Tribun Manado, 2018), saat ini narkoba sudah merambah kalangan remaja dan anak-anak, akan tetapi berkat kerjasama instansi terkait seperti Polisi, Bea cukai, angka yang cukup signifikan dari 5.1 juta pengguna mengalami penurunan sekitar 3.1 juta. Peredaran dan penyalahgunaan narkoba dan obat-obatan terlarang saat ini memang bukan hanya menyentuh orang dewasa saja tetapi sangat menyedihkan juga telah merambah sampai kepada anak-anak terutama yang usia sekolah dini seperti Sekolah Dasar melalui jenis jajanan (makanan ringan) yang telah dicampur dengan narkoba, seperti yang diungkapkan oleh Kepala Seksi Pencegahan dan Pemberdayaan Masyarakat, Badan Narkotika Nasional Kota (BNNK) Cimahi, Wahyu Harja Prayoga. Menurutnya anak-anak menjadi sasaran penyebaran narkotika, baik skala besar maupun skala kecil. Dimana skala kecil berupa obatobatan sperti obat batuk yang diminum dalam jumlah banyak dan melebihi dosis sehingga merasakan ngantuk dan pusing. Untuk itu, BNN terus giat melaksanakan sosialisasi dan pengawasan (Media Indonesia, 2018)

Kecamatan Bunaken Daratan masuk dalam wilayah administratif Kota Manado yang terletak paling utara. Jarak tempuh dari pusat kota Manado bisa 30 - 45 menit menggunakan kendaraan pribadi. Saat ini wilayah kecamatan Bunaken menjadi icon pariwisata di Kota Manado, sehingga beragam kegiatan seperti perlombaan paralayang yang bertaraf internasionalpun dilaksanakan di wilayah ini tepatnya di Gunung Tumpa, kelurahan Meras lingkungan III. Interaksi yang tercipta semakin luas antara masyarakat setempat dan wisatawan baik mancanegara maupun domestik, sehingga tidak menutup kemungkinan selain berdampak positif juga berdampak negatif, sehingga perlu adanya suatu langkah pencegahan dengan pengenalan sejak dini menyangkut dampak negatif yang bisa saja menyusup seperti penyalahgunaan obat-obatan terlarang seperti narkoba.

Menurut data penyalahgunaan Narkoba khususnya di Sulawesi Utara tergolong memprihatinkan dan perlu perhatian khusus, dimana jumlah pengguna sudah mencapai 42.876 (BNNP Sulut) golongan coba pakai mencapai 0.96\% sampai 1 tahun pakai menurut data tahun 2015 mencapai $2.43 \%$. Data BNNP Sulut menerangkan bahwa pengguna narkoba hampir menyentuh semua lapisan masyarakat seperti aparat pemerintah, pejabat, karyawan, ibu rumah tangga dan kalangan pelajar.

Narkoba dan obat-obat terlarang lain tidak hanya mengancam anak-anak muda atau orang dewasa, namun juga mengincar anak-anak. Oleh karena itu, kewaspadaan orangtua harus ditingkatkan dalam mengawasi kegiatan anakanak agar terhindar dari bahaya narkoba, selain 
itu orangtua wajib mengenalkan tentang bahaya narkoba yang dapat dimulai sejak anak duduk di sekolah dasar. Diperlukan cara yang tepat dalam memberikan edukasi tentang narkoba, sehingga membuat anak paham akan bahaya narkoba dan berusaha membentengi dirinya dari benda terlarang dan berbahaya ini

\section{Permasalahan Mitra}

Dewasa ini penggunaan narkotika bukan saja hanya mencakup orang dewasa saja yang sudah memiliki karier, akan tetapi data yang ada menunjukkan bahwa pengguna bahkan yang bertindak sebagai pengedar juga masih usia remaja atau pemuda, selain itu orang dewasa yang memanfaatkan anak kecil yang belum mengerti sebagai pengedar/penjual, yang masih mengenyam bangku pendidikan. Tentunya pendidikan bahkan pengetahuan sejak dini perlu dilakukan, selain ikut melibatkan diri untuk melakukan suatu langkah dalam perbaikan kualitas lingkungan hidup menyangkut perilaku yang menyimpang dalam penggunaan obatobatan terlarang dan narkoba, juga membekali pengetahuan lewat keluarga sangatlah penting meski kadang terabaikan. Untuk itu keberadaan ibu-ibu sebagai pilar dalam keluarga menjadi pertimbangan khusus untuk memberikan pembekalan pengetahuan lewat sosialisasi.

Informasi yang dikumpulkan oleh tim sebelum merencanakan program ini, yaitu kurangnya informasi menyangkut narkoba serta akibat yang ditimbulkannya. Lokasi mitra yang berada dibagian paling utara Kota Manado dimana akses informasinya cukup minim sehingga lebih mudah untuk bersentuhan dengan orang-orang yang terlibat narkoba, apalagi lokasi ini merupakan salah satu tujuan wisata. Banyak turis domestik maupun mancanegara yang mengunjungi wilayah ini. Untuk itu dibutuhkan suatu penyuluhan tentang bahaya dan pencegahan narkoba dengan melibatkan narasumber yang kompeten dibidangnya, baik itu dari bidang kesehatan serta lembaga yang bergerak dalam pemberantasan narkoba seperti BNN Kota Manado.

Kelompok ibu sebagai mitra dimaksudkan agar sejak dini ditanamkan pengetahuan tentang obat-obatan terlarang dan narkotika, baik bentuk dan bahayanya, agar benar-benar pengetahuan yang didapatkan dapat pergunakan untuk kehidupan terlebih saat menghadapi kehidupan yang sarat dengan narkoba dan pergaulan bebas untuk selanjutnya dapat di transfer pada anak-anak sejak dini.

\section{Tujuan dan Manfaat Kegiatan}

Sesuai dengan rencana kegiatan, maka luaran yang dihasilkan atau ditargetkan dalam kegiatan pengabdian pada masyarakat ini sebagai berikut. memberikan pembinaan melalui transfer pengetahuan kepada Kelompok ibu agar sejak dini ditanamkan pengetahuan tentang obat-obatan terlarang dan narkotika, baik bentuk dan bahayanya, agar benar-benar pengetahuan yang didapatkan dapat pergunakan untuk kehidupan, sehingga bermanfaat terlebih saat menghadapi kehidupan yang sarat dengan narkoba dan pergaulan bebas pada anak-anak

\section{METODE PELAKSANAAN Sasaran kegiatan}

Sasaran pelaksanaan kegiatan pelatihan ini adalah Kelompok Ibu di Bukit Doa Kelurahan Meras Kecamatan Bunaken Kota Manado. Anggota dalam kelompok ini merupakan ibu-ibu yang masih tergolong produktif dan memiliki anggota keluarga yang masih berusia 5 - 17 tahun.

\section{Lokasi kegiatan}

Lokasi kegiatan di Kelurahan Meras Lingkungan III melalui aplikasi zoom dari rumah masing-masing peserta. Kegiatan dilaksanakan selama 120 menit pada tanggal 15 Mei 2020 jam 17.00 Wita - 19.00 Wita dan diikuti oleh 30 orang peserta.

\section{Metode yang digunakan :}

Tahapan-tahapan yang kita lakukan untuk melaksanakan kegiatan Program Kemitraan Masyarakat ini melalui beberapa tahapan, diantaranya:

\section{Tahap pertama berupa ceramah}

Kegiatan ini meliputi transfer ilmu/ pengetahuan dari tim pelaksana yang melibatkan bidang kesehatan dan lembaga yang terkait dengan pemberantasan narkoba dan obat-obatan terlarang. Adapun materi sosialisasi yang akan disampaikan meliputi : 

a. Definisi narkoba dan obat-obatan terlarang
b. Jenis-jenis narkoba dan obat-obatan terlarang
c. Perkembangan penyalahgunaan narkoba dan obat-obatan terlarang
d. Peredaran narkoba dalam masyarakat
e. Bahaya narkoba dan obat-obatan terlarang
f. Bagaimana mencegah penyalahgunaan narkoba

Tahap kedua, kami akan melakukan kegiatan pengenalan tentang jenis narkoba melalui gambar dari bentuk obat-obatan yang tergolong dalam narkoba. Selain yang ditunjukkan oleh nara sumber secara langsung.

Tahap ketiga yaitu Memotivasi/Pelatihan Metode ini melalui tahapan transfer pengetahuan yang ditekankan pada langkah-langkah kongkrit dalam pencegahan yang telah diterapkan sebelumnya oleh instansi terkait pada masyarakat sehingga lebih mudah dimengerti oleh MITRA. Selanjutnya bagaimana memotivasi para ibu dengan langkah-langkah tersebut dan pengetahuan yang telah diterima dalam memberikan pendidikan tentang narkoba dan obat terlarang didalam keluarga, apalagi pada anak usia dini dan remaja. Diharapkan langkah ini dapat memotivasi para ibu sehingga memiliki semangat yang nantinya dapat menjadikannya bisa memiliki kemampuan memotivasi dalam kehidupan bermasyarakat.

Beberapa cara dalam memotivasi dan memberikan pengetahuan pada anak tentang narkoba dapat dilakukan melalui langkah-langkah sebagai berikut :

a. Membicarakan secara langsung dan terbuka pada anak tentang narkoba

b. Memperkenalkan sedini mungkin

c. Melakukan Penelitian Pribadi Mengenai Narkoba dengan aktif mengikuti setiap pemberitaan baik dari media massa, elektronik maupun internet

d. Mempertahakan jalur komunikasi yang terbuka dengan anak

Mampu mendefinisikan maksud dan bagaimana kecanduan pada anak-anak

Definisikan Sejak Awal Apa itu Narkoba

Bicarakan Mengenai Apa yang Anak Lihat di Televisi Mengenai Narkoba

Memuji anak terkait perilaku mereka yang benar Pemberian Reward
Sebagai bentuk ucapan terima kasih atau penghargaan kepada para peserta, diberikan penggantian uang pulsa/kuota dan penyerahan sembako kepada setiap keluarga peserta yang mengikuti kegiatan mengingat saat ini terkena dampak pandemic corona.

\section{HASIL DAN PEMBAHASAN}

Kegiatan ini awalnya dijadwalkan untuk tatap muka dalam bentuk penyuluhan/sosialisasi/ceramah kepada peserta yang terdiri dari dua kelompok ibu, akan tetapi mengingat waktu pelaksanaan pada saat pandemic corona yang mengharuskan untuk menjaga jarak dan menjauhi kerumunan maka kegiatan dilaksanakan hanya melalui aplikasi Zoom. Meski demikian kegiatan tetap dapat berlangsung dengan baik berkat dukungan kelompok ibu yang ada berserta keluarga dan semua yang terkait didalam pelaksanaannya.

Narkotika adalah zat atau obat baik yang bersifat alamiah, sintetis, maupun semi sintetis yang menimbulkan efek penurunan kesadaran, halusinasi, serta daya rangsang (BNN RI, 2019), sedangkan menurut UU Narkotika pasal 1 ayat 1 menyatakan bahwa narkotika merupakan zat buatan atau pun yang berasal dari tanaman yang memberikan efek halusinasi, menurunnya kesadaran, serta menyebabkan kecanduan. Adapun jenis narkoba terbagi dalam 3 golongan berdasarkan resiko ketergantungan yaitu golongan 1 seperti ganja, opium, dan tanaman koka sangat berbahaya jika dikonsumsi karena beresiko tinggi menimbulkan efek kecanduan. Golongan 2 bisa dimanfaatkan untuk pengobatan asalkan sesuai dengan resep dokter. Jenis dari golongan ini kurang lebih ada 85 jenis, beberapa diantaranya seperti Morfin, Alfaprodina, dan lainlain. Golongan 2 juga berpotensi tinggi menimbulkan ketergantungan. Golongan 3 memiliki risiko ketergantungan yang cukup ringan dan banyak dimanfaatkan untuk pengobatan serta terapi. Jenis Narkotika Sintesis sering dimanfaatkan untuk keperluan pengobatan dan juga penelitian. Contoh dari narkotika yang bersifat sintetis seperti Amfetamin, Metadon, Deksamfetamin, dan sebagainya. Sedangkan jenis semi sintetis berupa narkotika alami yang 
kemudian diisolasi dengan cara diekstraksi atau memakai proses lainnya. Contohnya adalah Morfin, Heroin, Kodein, dan lain-lain (BNN RI, 2019).

Adapun beberapa bahaya dan dampak dari narkoba terhadap kesehatan meliputi terjadinya dehidrasi yang berujung padang kerusakan otak, halusinasimenjadi salah satu efek yang sering dialami oleh pengguna narkoba seperti ganja. Apabila pemakaian berlangsung lama, bisa mengakibatkan dampak yang lebih buruk seperti gangguan mental, depresi, serta kecemasan terus-menerus. Efek lainnya yaitu menurunnya tingkat kesadaran sehingga beresiko pada hilangnya ingatan dan dampak lainnya yaitu kehilangan nyawa (BNN RI, 2019).

Materi ceramah (Gambar 1) yang diberikan secara langsung melalui zoom, selanjutnya dibagikan dalam bentuk hardcopi pada masing-masing peserta di rumah masingmasing setelah kegiatan dilaksanakan pada esok harinya. Pada awalnya sesuai latar belakang permasalahan mitra yang masih belum jelas mengetahui pemahamannya tentang narkoba, ternyata begitu antusias dan setelah dilakukan tanya jawab setelah pemberian materi ternyata para peserta telah memahami tentang bahaya dan bagaimana langkah dalam menanggulangi penggunaannya pada remaja dan anak-anak. Hal tersebut sesuai dengan yang disebutkan oleh Jumaidah dan Rindu (2017) hubungan positif antara pengetahuan tentang narkoba terhadap tindakan pencegahan, semakin tinggi pengetahuan terhadap narkoba maka semakin tinggi pula pencegahan terhadap narkoba.

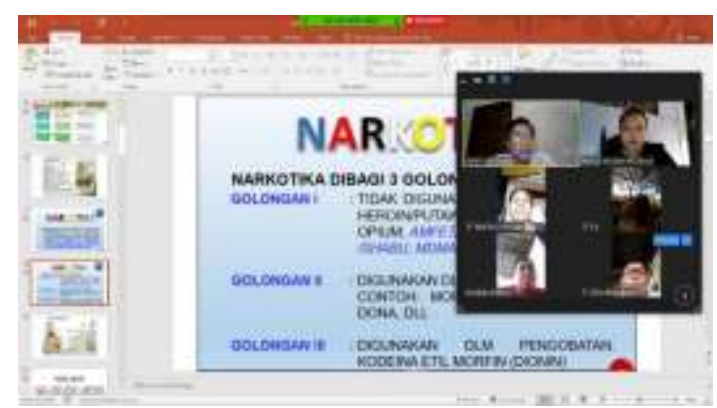

Gambar 1. Materi Pengabdian

Berdasarkan diskusi dalam kegiatan tersebut ditemukan bahwa para orang tua tidak mengetahui bahwa saat ini narkoba sudah beredar juga dalam kemasan permen atau bentuk-bentuk yang menarik untuk dipasarkan ke anak-anak, bahkan dari diskusi tersebut sama-sama mencari solusi terbaik bahwa pendidikan/ pengetahuan tentang narkoba sangat penting untuk diberikan sejak dini dari dalam keluarga, orang tua harus pintar dan mengikuti setiap perkembangan dalam perdagangan narkoba dan bentuk-bentuknya sehingga bisa mengingatkan anggota keluarganya.

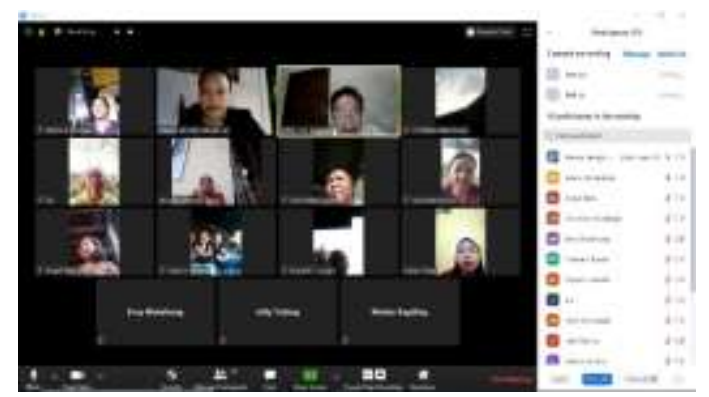

Gambar 2. Diskusi Pengabdian

Peserta yang terdiri dari ibu-ibu, remaja, pemuda bahkan bapak-bapakpun bertekad kedepannya bersama untuk saling memberikan semangat dan motivasi bagi anggota keluarga masing-masing. Jika ada anggota keluarga yang telah tersentuh atau dicurigai menggunakan narkoba maka harus segera ditangani melalui rehabilitasi juga kerjasama dengan instansi terkait agar secepatnya ditangani tanpa perlu takut sebelum benar-benar merusak para penerus bangsa ini. Hal menyangkut rehabilitasi disebutkan juga dalam UU No. 9 tahun 1976 yaitu usaha memulihkan untuk menjadikan pecandu narkotika hidup sehat jasmaniah dan atau rohaniah sehingga dapat menyesuaikan dan meningkatkan kembali ketrampilannya, pengetahuannya serta kepandaiannya dalam lingkungan hidup. Penting untuk diingat bahwa keluarga memiliki pengaruh yang sangat penting sebagai awal dari suatu pendidikan usia dini, seperti halnya penelitian yang dilakukan oleh Wisnatul et al (2014) menemukan bahwa keluarga sebagai tempat utama untuk mengendalikan perilaku remaja, memiliki posisi tertentu di antara alasan kecenderungan penyalahgunaan narkoba. Dalam hal ini, perceraian orang tua, konlik keluarga, dan kelalaian anak selalu dianggap sebagai faktor yang efektif dalam kecanduan narkoba. Remaja hasil dari perceraian memiliki risiko kecanduan narkoba yang tinggi. Untuk Kelompok wanita 
yang dipilih, memiliki keluarga yang lengkap dan tergolong keluarga dalam kehidupan sederhana dan bahagia. Selain itu belum ditemukan anggota keluarga yang telah memakai narkoba atau obat terlarang lainnya.

\section{KESIMPULAN DAN SARAN}

Berdasarkan kegiatan yang telah dilakukan dapat disimpulkan bahwa terjadi peningkatan pengetahuan masyarakat khususnya ibu-ibu tentang Narkoba, bahaya dan penanggulangannya, kemudian masyarakat lebih memahami tentang cara untuk melakukan pencegahan sejak dini pada anggota keluarganya mengenai narkoba dan mampu menjelaskan dengan baik tentang jenis-jenis dan bentuk penyebebaran narkoba, sehingga sejak dini dapat mengantisipasi dan membantu memutus mata rantai penyebaran narkoba terutama pada anggota masyarakat usia dini.

Kedepannya kegiatan seperti harus terus ditingkatkan melalui penyuluhan/sosialisasi dalam bentuk ceramah kepada masyarakat dilokasi lainnya, serta perlu adanya monitoring untuk memotivasi setiap orang agar semangat dalam memerangi narkoba.

\section{UCAPAN TERIMA KASIH}

Terima kasih kepada Lembaga Penelitian dan Pengabdian Masyarakat Universitas Sam Ratulangi (LPPM- Unsrat) yang telah membiayai kegiatan Program Kemitraan Masyarakat tahun pendanaan 2020 ini. Terima kasih juga disampaikan kepada mitra kegiatan ini yaitu kelompok ibu Bukit Doa Meras Kecamatan Bunaken Kota Manado.

\section{DAFTAR PUSTAKA}

BNN RI. 2019. Pengertian Narkoba dan Bahaya Narkoba bagi Kesehatan. https://bnn.go.id/pengertian-narkobadan-bahaya-narkoba-bagikesehatan/\#: :text=Pengertian\%20Nark oba\%20(Narkotika\%20dan\%20Obat, $\% 2$ C\%20halusinasi\%2C\%20serta\%20daya \%20rangsang.\&text=Obat\%2Dobatan\% 20tersebut\%20dapat $\% 20$ menimbulkan $\%$ 20kecanduan\%20jika\%20pemakaiannya $\%$ 20berlebihan.

Jumaidah, Rindu. 2017. Perilaku Pencegahan Penyalahgunaan Narkoba Pada Remaja
Di Wilayah Kecamatan Sukmajaya, Depok. Jurnal Ilmiah Kesehatan 42 Vol. 16 Nomor 3.

Media Indonesia. Narkoba sasar anak sekolah tingkat dasar .https://mediaindonesia.com/read/detail/ 114548-narkoba-sasar-anak-sekolahtingkat-dasar

Tribun Manado, 2018. BNN : Narkoba Sudah Merambah Kalangan Remaja dan Anakanak,

https://manado.tribunnews.com/2018/12 /13/bnn-narkoba-sudah-merambahkalangan-remaja-dan-anak-anak. Media Indonesia.

UNDANG-UNDANG NEGARA REPUBLIK INDONESIA NOMOR 7 TAHUN 1997 Tentang Pengesahan United Nations Convention Againts Illicit Traffic In Narcotic Drugs And Psychotropic Substances, $1988 \quad$ (Konvensi Perserikatan Bangsa-Bangsa Tentang Pemberantasan Peredaran Gelap Narkotika Dan Psikotropika.

Undang-undang No.9 Tahun 1976 Tentang Narkotika

Wisnatul, dkk. 2014. Faktor-Faktor Yang Berhubungan Dengan Upaya Orang Tua Dalam Pencegahan Penyalahgunaan Narkoba Pada Remaja Di Jorong Kubang Duo Koto Panjang Nagari Bukik Batabuah Kecamatan Canduang Kabupaten Agam Tahun 2014 [KTI], Diploma Tiga Keperawatan STIKES Yarsi, SUMBAR BUKIT TINGGI. 